\title{
ANALISIS KONSENTRASI GAS KARBON MONOKSIDA (CO) PADA RUAS JALAN GAJAH MADA PONTIANAK
}

\author{
Sendi Yulianti ${ }^{1}$, Yulisa Fitrianingsih,ST.MT ${ }^{1}$, Dian Rahayu Jati,ST.MT ${ }^{1}$ \\ ${ }^{1}$ Program Studi Teknik Lingkungan, Fakultas Teknik, Universitas Tanjungpura, Pontianak \\ sendi.yulianti@yahoo.co.id
}

\begin{abstract}
ABSTRAK
Karbon Monoksida (CO) merupakan salah satu penyumbang pencemaran udara yang berasal dari sektor transportasi akibat dari buangan pembakaran mesin yang kurang sempurna. Jalan Gajah Mada Pontianak merupakan salah satu jalan yang padat lalu-lintas. Tujuan penelitian ini adalah untuk mengetahui di titik dan pada variasi jarak berapakah kadar konsentrasi gas karbon monoksida (CO) tertingi di ruas Jalan Gajah Mada Pontianak, bagaimana pengaruh konsentrasi CO dengan variasi pengambilan jarak (0m, 5m dan $10 \mathrm{~m})$ dari sumber yang berada di badan jalan serta bagaimana pengaruh kondisi parameter metereologi seperti suhu, arah angin dan kecepatan angin terhadap nilai konsentrasi gas karbon monoksida (CO). Jenis penelitian adalah analitik observasional dengan konsentrasi gas karbon monoksida (CO) dan parameter metereologi berupa arah dan kecepatan angin serta suhu merupakan variabel terikat dan variabel bebas berupa jarak pengambilan dengan jarak $0 \mathrm{~m}, 5 \mathrm{~m}$, dan $10 \mathrm{~m}$ dari sumber. Hasil penelitian yang dilakukan setiap hari Kamis (mewakili hari kerja) dan setiap hari Minggu (mewakili hari libur) di bulan September 2013 menunjukkan hasil konsentrasi tertinggi di dapatkan pada hari kerja dengan nilai konsentrasi CO sebesar $19.955 \mu \mathrm{g} / \mathrm{Nm}^{3}$ dengan kecepatan angin saat pengukuran adalah sebesar $0,1 \mathrm{~m} / \mathrm{s}$ dan suhu sebesar $27,7{ }^{\circ} \mathrm{C}$ dan pada hari libur didapatkan nilai konsentrasi gas karbon monoksida (CO) sebesar $24.944 \mu \mathrm{g} / \mathrm{Nm}^{3}$ dengan kecepatan angin saat pengukuran adalah sebesar $0,2 \mathrm{~m} / \mathrm{s}$ dan suhu sebesar $28,7{ }^{\circ} \mathrm{C}$ yang berada pada titik yang sama yaitu pada titik 6 yang terdapat pada persimpangan Jalan Gajah Mada, Jalan Veteran dan Jalan Pahlawan dengan jarak Om. Berdasarkan analisis statistik dengan Kruskal Wallist Test menunjukkan $H \leq X^{2} \alpha$; K-1, artinya terdapat perbedaan yang signifikan antara perbedaan jarak dalam pengambilan konsentrasi CO. Semakin jauh jarak pengambilan dari sumber maka nilai konsentrasi CO akan semakin berkurang. Parameter metereologi berupa suhu yang tinggi akan menyebabkan tingginya nilai konsentrasi CO. Sedangkan pengaruh dari kecepatan angin yang tinggi akan menyebabkan nilai konsentrasi $\mathrm{CO}$ akan berkurang.
\end{abstract}

Kata kunci : Konsentrasi CO, jarak pengambilan sampel, parameter metereologi

\begin{abstract}
Carbon Monoxide (CO) is one of the contributor to air pollution from the transport sector as a result of combustion engine exhaust is less than perfect. Gajah Mada Pontianak highway is one busy road traffic. The aim of this study was to determine at what distance point and the concentration levels of carbon monoxide (CO) highest in Gajah Mada Pontianak highway, the influence of variations in the concentration of CO with distancing $(0 \mathrm{~m}, 5 \mathrm{~m}$ and $10 \mathrm{~m})$ from sources that are on the road and how the influence of meteorological parameters such as temperature conditions, wind direction and wind speed to the value of the concentration of carbon monoxide (CO). This type of research is observational analytic concentration of carbon monoxide (CO) and meteorological parameters such as wind speed and direction and temperature is the dependent variable and independent variables such as distance-making with distance $0 \mathrm{~m}, 5 \mathrm{~m}$, and $10 \mathrm{~m}$ from the source. Results of research conducted every Thursday (representing working days) and every Sunday (representing holidays) in the month of September 2013 showed the highest concentration results in getting on weekdays with a value of $19955 \mu \mathrm{g} / \mathrm{Nm}^{3} \mathrm{CO}$ concentrations with wind speed at the time of measurement is $0,1 \mathrm{~m} / \mathrm{s}$ and a temperature of $27,7^{\circ} \mathrm{C}$ and the holiday gas concentration values obtained carbon monoxide (CO) by $24.944 \mu \mathrm{g} / \mathrm{Nm}^{3}$ with current wind speed measurement is $0,2 \mathrm{~m} / \mathrm{s}$ and a temperature $28.7^{\circ} \mathrm{C}$ and they are at the same point, in point 6 found it in the intersection of Gajah Mada highway and Veteran higahway with a distance of Om. Based on statistical analysis with Kruskal Wallist Test shows $H \leq X^{2} \alpha ; K-1$, meaning that there are significant differences between the differences in decision-concentration $\mathrm{CO}$ distance. The farther distance from the source making the value of the concentration of $\mathrm{CO}$ will decrease._Meteorological parameters such as high temperatures will cause high concentrations of $\mathrm{CO}$ values. While the effect of high wind speeds will cause the value of $\mathrm{CO}$ concentration will be reduced.
\end{abstract}

Key words: Concentration of $\mathrm{CO}$, distance sampling, meteorological parameters 


\section{I.PENDAHULUAN}

\section{A. Latar Belakang}

Salah satu daerah dengan kepadatan kendaraan tertinggi adalah pada ruas Jalan Gajah Mada Pontianak. Jalan tersebut dianggap paling sibuk aktifitas transportasinya karena terdapat beberapa pusat perdagangan, perkantoran, persekolahan serta beberapa tempat penginapan. Hal ini diperkuat dengan adanya data dari Dinas Perhubungan yang menyatakan adanya peningkatan jumlah kendaraan yang melewati Jalan Gajah Mada Pontianak. Dinas Perhubungan Kota Pontianak menyatakan di Jalan Gajah Mada Pontianak pada tahun 2009 tercatat sebanyak 867 kendaraan pada saat jam puncak meningkat menjadi 1.191 kendaraan pada tahun 2012.

Tingginya kepadatan kendaraan di suatu wilayah akan mengakibatkan tingginya pencemaran udara di daerah tersebut. Salah satu gas pencemar yang dihasilkan dari sektor transportasi ini adalah gas Karbon monoksida (CO). CO diketahui dapat mempengaruhi kerja jantung, sistem syaraf pusat, juga janin dan dapat mempengaruhi saluran pernafasan yang dapat menyebabkan kekurangan oksigen dan berujung pada kematian. CO yang terakumulasi dengan gas lainnya di udara dapat menimbulkan keracunan bagi manusia dalam bentuk $\mathrm{COHb}$ (karboksihemoglobin) pada darah. $\mathrm{CO}$ juga dapat menyebabkan kejang berlanjut yang mengakibatkan ketidaksadaran dan berujung pada kematian.

Pada penelitian ini dilakukan pengukuran konsentrasi gas karbon monoksida (CO) sebagai objek penelitian untuk mengetahui di titik manakah kadar konsentrasi gas karbon monoksida (CO) terbesar dan adakah hubungan antara jarak pengambilan dengan nilai konsentrasi CO yang di dapatkan.

\section{TINJAUAN PUSTAKA}

\section{A. Pencemaran Udara}

Pencemaran udara diartikan sebagai adanya bahan-bahan atau zat-zat asing di dalam udara yang menyebabkan perubahan susunan (komposisi) udara dari keadaan normalnya. Sumber pencemar udara dibedakan atas sumber tidak bergerak seperti cerobong asap dan pembakaran terbuka di wilayah pemukiman dan sumber bergerak seperti kendaraan bermotor di jalan raya (Praja, 2006). Menurut Wardhana (2004) perkiraan presentase pencemar udara terbesar dari sumber transportasi di Indonesia adalah pada gas CO yaitu sebesar 70,50\%, gas pencemar kedua yaitu Nox, SOx, HC dan partikel. Karbon monoksida (CO) adalah suatu gas yang tak berwarna, tidak berbau dan juga tidak berasa. Gas CO dapat berbentuk cairan pada suhu dibawah $-192^{\circ} \mathrm{C}$. Gas CO sebagian besar berasal dari pembakaran bahan bakar fosil dengan udara, berupa gas buangan (Wardhana, 2004).

Fardiaz (1992) menyatakan bahwa konsentrasi CO di udara per waktu dalam satu hari dipengaruhi oleh kesibukan atau aktivitas kendaraan bermotor. Semakin ramai kendaraan bermotor yang ada, semakin tinggi tingkat polusi CO di udara. Terpaparnya gas pencemar berupa $\mathrm{CO}$ dalam darah ( $\mathrm{COHb}$ ) pada manusia ini akan mengakibatkan penurunan kapasitas darah untuk mengikat oksigen. Kadar $\mathrm{COHb}$ dalam akan naik apabila $\mathrm{CO}$ meningkat dan aktifitas fisik juga meningkat. Paparan yang berlebihan pada manusia akan mengakibatkan pengrusakan penglihatan dan kesadaran, fungsi sistem kontrol syaraf turun serta fungsi jantung dan paruparu menurun bahkan dalam kondisi yang berlebihan dapat menyebabkan kematian.

\section{B. Dampak Gas Karbon Monoksida (CO) Terhadap Manusia}

Gas CO dalam konsentrasi tinggi dapat menyebabkan gangguan kesehatan, bahkan juga dapat menyebabkan kematian. Gas CO apabila terhisap ke dalam paru-paru akan mengikuti peredaran darah dan akan menghalangi masuknya oksigen $\left(\mathrm{O}_{2}\right)$ yang dibutuhkan oleh tubuh. Hal ini dapat terjadi karena gas $\mathrm{CO}$ bersifat racun metabolis, ikut bereaksi secara metabolis dengan darah menjadi karboksihemoglobin ( $\mathrm{COHb})$. Ikatan karboksihemoglobin jauh lebih stabil dari pada ikatan oksigen dengan darah (oksihemoglobin). Keadaan ini menyebabkan darah 
menjadi lebih mudah menangkap CO dan menyebabkan fungsi vital darah sebagai pengangkut oksigen terganggu.

Konsentrasi $\mathrm{CO}_{2}$ di udara sekitar $80 \mathrm{ppm}$ dan konsentrasi $\mathrm{COHb}$ dalam darah sekitar $13 \%$, maka seseorang akan sulit bernapas, bila konsentrasi semakin tinggi serta terjadi dalam waktu lama dapat berakibat seseorang pingsan bahkan sampai kematian. Keracunan kronis akan mengakibatkan ganguan syaraf pusat dengan gejala fisik dan gangguan mental.

\section{Faktor yang Mempengaruhi Kualitas Udara}

Faktor-faktor yang mempengaruhi kualitas udara adalah sebagai berikut:

1. Arah dan Kecepatan Angin

Kecepatan angin pada dasarnya ditentukan oleh perbedaan tekanan udara antara tempat asal dan arah angin sebagai faktor pendorong. Secara umum polutan-polutan di atmosfer terdispersi dalam 2 cara yaitu melalui kecepatan angin dan turbulensi atmosfer. Turbulensi menyebabkan terjadinya aliran udara melalui 2 cara yaitu pusaran termal dan pusaran mekanis (Zendrako, 2010).

2. Kelembaban dan Suhu Udara

Di atmosfer akan terjadi penurunan suhu dan tekanan sesuai dengan pertambahan tinggi. Udara ambien mempengaruhi terbentuknya stabilitas atmosfer. Gerakan ke bawah akan menghasilkan sekumpulan udara yang lebih hangat dan akan kembali ke elevasi semula. Dalam kondisi atmosfer seperti ini, gerakan vertikal akan diabaikan oleh proses pendinginan adiabatik atau pemanasan, dan atmosfer akan menjadi stabil. Jika sekumpulan udara terbawa ke atas akan melalui bagian yang mengalami penurunan tekanan dan akibatnya kumpulanan udara itu akan menyebar. Ekspansi tadi memerlukan kerja untuk melawan lingkungannya dan terjadi penurunan temperatur.

\section{Statistika}

Statistika merupakan suatu ilmu pengetahuan yang berhubungan dengan data statistik dan fakta yang benar, atau suatu kajian ilmu pengetahuan dengan teknik pengumpulan data, teknik pengolahan data, teknik analisis data, penarikan kesimpulan, dan pembuatan kebijakan yang cukup kuat alasannya berdasarkan data dan fakta yang benar (Riduwan, 2011).

Metode pengolahan yang digunakan peneliti yaitu metode perhitungan Kruskall Wallis. Pengujian melalui metode Kruskall Wallis merupakan metode pengembangan dari metode analisis varians satu araah (one way analysis of variance). Metode ini digunakan untuk membandingkan tiga atau lebih kelompok sampel dengan hasil akhir berupa nilai signifikan yang menyatakan adanya hubungan antara parameter yang diteliti. Langkah-langkah yang dilakukan dalam pengujian Kruskall Wallis yaitu :

\section{Merumuskan hipotesis}

Perumusan hipotesis dalam penelitian terdiri dari dua hipotesis yaitu hipotesis null atau (HO) dan hipotesis alternatif ( $\mathrm{Ha}$ ). Hipotesis null ( $\mathrm{HO})$ menyatakan tidak adanya hubungan, pengaruh dan perbedaan antara parameter dengan statistik lawannya. Sedangkan hipotesis alternatif $\mathrm{(Ha}$ ) adanya hubungan, pengaruh dan perbedaan antara parameter dan statistiknya. Perumusan kedua hipotesis dikemukaan secara lebih rinci dan khusus, hal itu disesuaikan dengan konteks keadaan (Fitri, 2012). Apabila di dalam pernyataan didapatkan bahwa HO "ditolak" maka hipotesis Ha akan di terima sedangkan apabila di dalam pernyataan di dapatkan $\mathrm{Ha}$ "diterima" maka hipotesis null ( $\mathrm{HO})$ di terima.

2. Menentukan taraf signifikansi tertentu

Nilai taraf signifikasi atau nilai derajat signifikan adalah kesalahan taksiran. Biasanya dalam penelitian kesalahan taksiran atau nilai derajat kesalahan terlebih dahulu. Umumnya yang digunakan adalah $5 \%(\alpha=0,05)$ dan $1 \%(\alpha=0,01)$ dengan derajat kepercayaan yaitu $95 \%$ $(100 \%-5 \%=95 \%)$ dan $99 \%(100 \%-1 \%=99 \%)$.

\section{Merumuskan kriteria pengujian}

Perumusan kriteria pengujian yang diberlakukan secara umum yaitu sebagai berikut : 
HO ditolak apabila : $\mathrm{H} \leq \mathrm{X}^{2} \alpha ; \mathrm{K}-1$ dan

$\mathrm{HO}$ diterima apabila: $\mathrm{H}>\mathrm{X}^{2} \alpha ; \mathrm{K}-1$

Keterangan :

$\mathrm{H} \quad$ : Asymp. Sig.

$\mathrm{X}^{2} \alpha ; \mathrm{K}-1$ : nilai chi-square ; df

\section{METODE PENELITIAN}

\section{A. Lokasi dan Waktu Penelitian}

Lokasi penelitian dilakukan pada ruas Jalan Gajah Mada. Adapun lokasi-lokasi yang dipilih untuk melakukan penelitian ini dapat di lihat pada tabel berikut :

Titik 1 : Persaimpangan JIn.Gajah Mada-Jln. H.Agus Salim

Titik 2 : Jalan Siam

Titik 3 : Jalan Dr.Setia Budi

Titik 4 : Jalan Ketapang

Titik 5 : Jalan Hijas

Titik 6 : Persimpangan Jln. Gajah Mada-Jln Veteran - Jln.Pahlawan

Waktu penelitian dilakukan pada hari Kamis (mewakili hari kerja) dan Minggu (mewakili hari libur) dan dilakukan pada saat jam puncak sesuai data yang telah di peroleh sebelumnya dari penelitian Firda Masitah dan didapatkan waktu yaitu pada pukul 06.45 - 08.45 WIB pada hari kamis dan pukul $18.45-20.45$ WIB pada hari minggu. Jarak pengambilan sampel berdasarkan SNI.No.19-7119.9-2005 dilakukan pada jarak 0m, 5m dan $10 \mathrm{~m}$ dari sumber pencemar. Pengambilan sampel dilakukan selama 4 minggu di bulan September yaitu:

1. Hari kerja, pada hari Kamis pada tanggal 5 September 2013, 12 September 2013, 19 September 2013, dan 26 September 2013.

2. Hari Libur, pada hari Minggu pada tanggal 8 September 2013, 15 September 2013, 22 September 2013, 29 September 2013.

\section{B. Jenis dan Variabel Penelitian}

Penelitian ini termasuk jenis penelitian observasional analitik, yaitu penelitian yang digunakan untuk mencari hubungan antara variabel bebas dengan variabel terikat yang digunakan untuk menentukan ada tidaknya hubungan antar variabel.

\section{Teknik dan Alat Pengumpul Data}

Teknik pengumpulan data yang digunakan berupa pengambilan sampel gas karbon monoksida (CO) dengan menggunakan alat CO Meter dengan seri Lutron GCO-2008 dan pengambilan sampel parameter metereologi dengan menggunakan alat Wind Meter dengan seri ADC Wind Silva berupa arah dan kecepatan angin, serta suhu.

\section{Analisis Data}

Analisis data yang digunakan berupa :

1. Analisis statistik deskriptif digunakan untuk mengetahui konsentrasi $\mathrm{CO}$ tertinggi.

2. Analisis statistik Non Parametik Kruskall-Wallis digunakan untuk mengetahui pengaruh jarak terhadap konsentrasi CO.

\section{GAMBARAN UMUM LOKASI}

\section{A. Jalan Gajah Mada Pontianak}

Secara geografis jalan Gajah Mada Pontianak berada di 5 (lima) Kelurahan, dengan luas mencapai $15,14 \mathrm{~km}^{2}$, dan jumlah penduduk sebanyak 81.821 jiwa.

Jalan Gajah Mada Pontianak ini memiliki panjang $\pm 1,5 \mathrm{~km}$ dengan lebar $\pm 8 \mathrm{~m}$. Ruas jalan Gajah Mada Pontianak pada bagian timur dan barat dibatasi oleh perempatan rambu lalu lintas, yaitu sebagai pertemuan arus dari berberapa jalan di sekitarnya. Pada bagian selatan merupakan pertemuan arus dari jalan Veteran, Jalan Budikarya dan jalan Pahlawan. Sedangkan pada bagian 
utara di batasi oleh Jalan Hoscokroaminoto, Jalan Patimura dan Jalan Diponegoro. Berikut ini merupakan gambar Jalan Gajah Mada Pontianak.

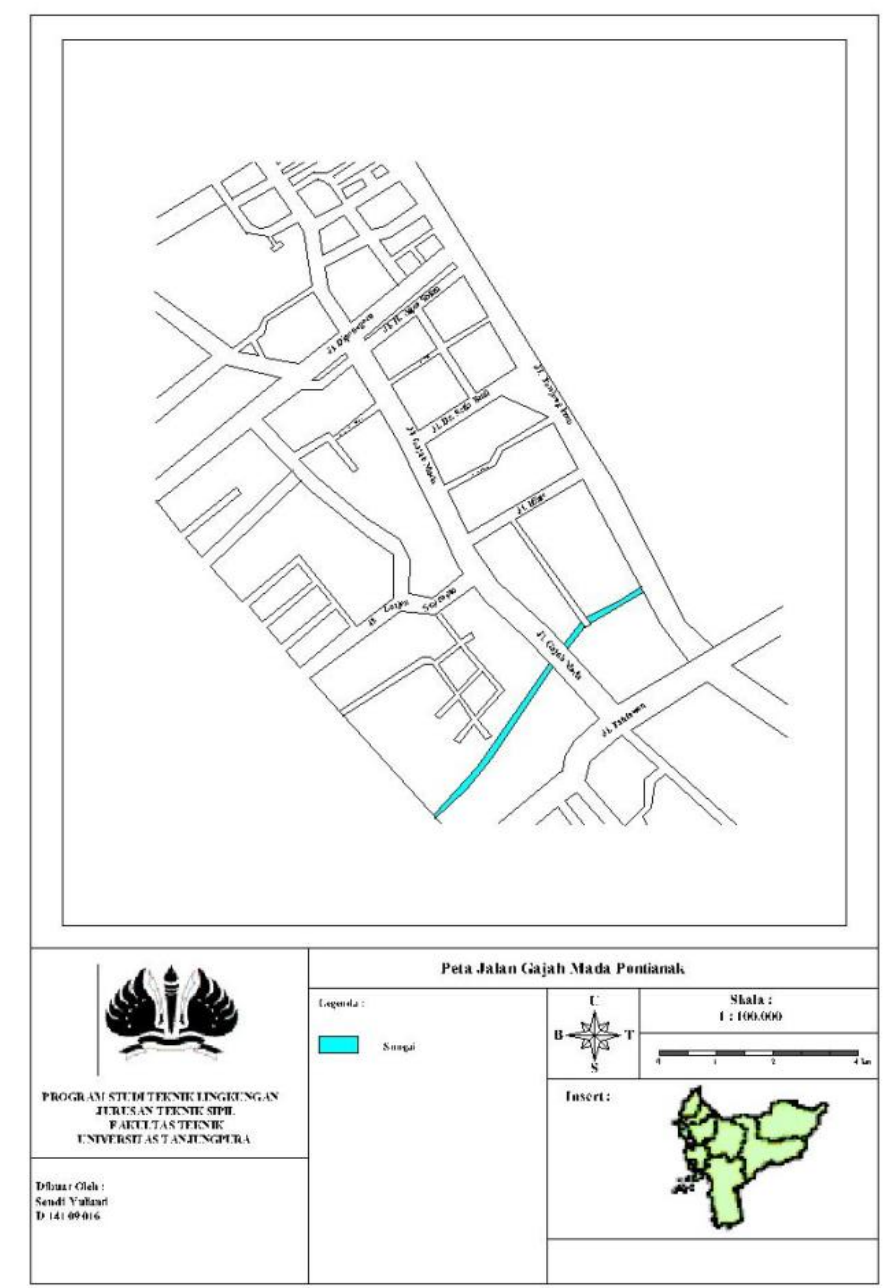

Gambar 1. Peta Jalan Gajah Mada Pontianak

Banyaknya volume kendaraan di Jalan Gajah Mada pada tahun 2012 di dapatkan hasil sebanyak 1.826 kendaraan pada saat jam puncak yaitu pukul $06.45-08.45$ WIB. Hasil tersebut dapat dilihat tabel 2 berikut ini :

Tabel 2. Volume Kendaraan Pada Saat Jam Puncak

\begin{tabular}{|c|r|r|r|r|}
\hline Waktu & \multicolumn{1}{|c|}{ MC } & \multicolumn{1}{|c|}{ LV } & HV & Jumlah \\
\hline $06.45-07.00$ & 296 & 57 & 0 & 353 \\
\hline $07.00-07.15$ & 221 & 41 & 1 & 262 \\
$07.15-07.30$ & 212 & 43 & 0 & 256 \\
$07.30-07.45$ & 189 & 43 & 1 & 233 \\
$07.45-08.00$ & 112 & 43 & 1 & 157 \\
$08.00-08.15$ & 90 & 40 & 0 & 130 \\
$08.15-08.30$ & 168 & 49 & 1 & 218 \\
$08.30-08.45$ & 166 & 50 & 2 & 218 \\
\hline TOTAL & 1.454 & 366 & 6 & 1826 \\
\hline
\end{tabular}

a. Pada Hari Kerja

\begin{tabular}{|c|r|r|r|r|}
\hline Waktu & \multicolumn{1}{|c|}{ MC } & \multicolumn{1}{c|}{ LV } & \multicolumn{1}{|c|}{ HV } & Jumlah \\
\hline $06.45-07.00$ & 296 & 57 & 0 & 353 \\
\hline $07.00-07.15$ & 221 & 41 & 1 & 262 \\
$07.15-07.30$ & 212 & 43 & 0 & 256 \\
$07.30-07.45$ & 189 & 43 & 1 & 233 \\
$07.45-08.00$ & 112 & 43 & 1 & 157 \\
$08.00-08.15$ & 90 & 40 & 0 & 130 \\
$08.15-08.30$ & 168 & 49 & 1 & 218 \\
$08.30-08.45$ & 166 & 50 & 2 & 218 \\
\hline TOTAL & 1.454 & 366 & 6 & 1826 \\
\hline
\end{tabular}

b. Pada Hari Libur

Sumber : Firda Masitah,2012

Keterangan : $\square$ merupakan jumlah kendaraan tartinggi dengan MC : Kendaraan roda 2, LV : Kendaraan roda 4, HV : Kendaraan roda lebih dari 5. 
Dari tabel tersebut terlihat bahwa kepadatan tertinggi di hari kerja di dapatkan pada pukul 06.45-08.45 WIB, dengan jumlah kendaraan tertinggi berada pada pukul 06.45 - 07.00 WIB. Sedangkan pada hari libur kepadatan kendaraan tertinggi terjadi pada pukul $18.45-20.00$ WIB dengan jumlah kendaraan tertinggi yaitu pukul $19.45-20.00$ WIB.

Berdasarkan hasil jumlah kepadatan kendaraan terbanyak inilah yang menjadi dasar dilakukannya pengukuran konsentrasi gas karbon monoksida (CO) di Jalan Gajah Mada Pontianak.

\section{HASIL DAN PEMBAHASAN}

\section{A. Data Primer Konsentrasi Gas Karbon Monoksida (CO) di Hari Kerja dan Hari Libur}

Berikut ini merupakan gambar grafik nilai konsentrasi CO di semua titik pada hari kerja. Gambar grafik tersebut dapat terlihat pada gambar 1 berikut ini :

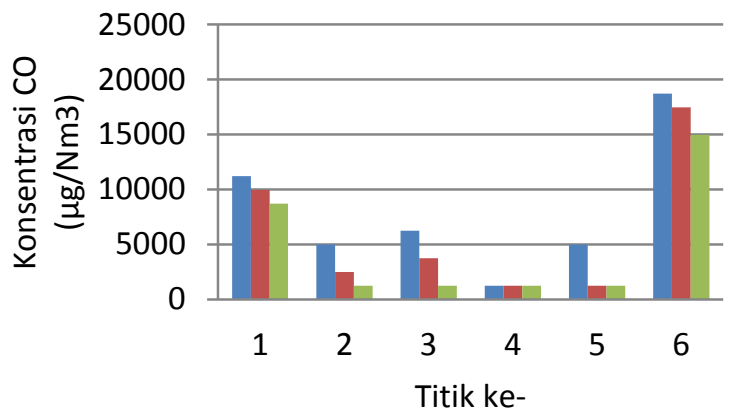

a. Kamis ke-1

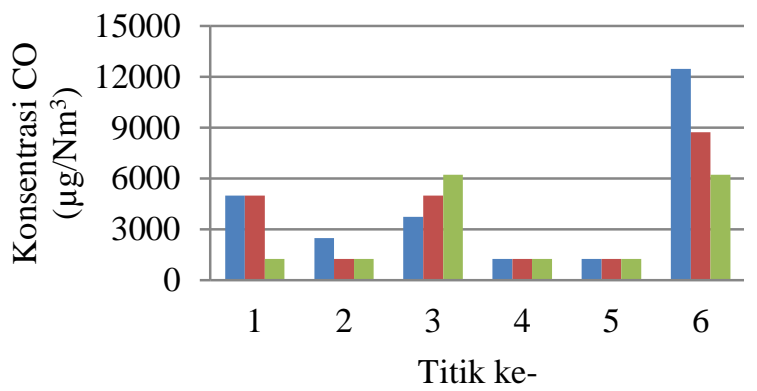

b. Kamis ke-2

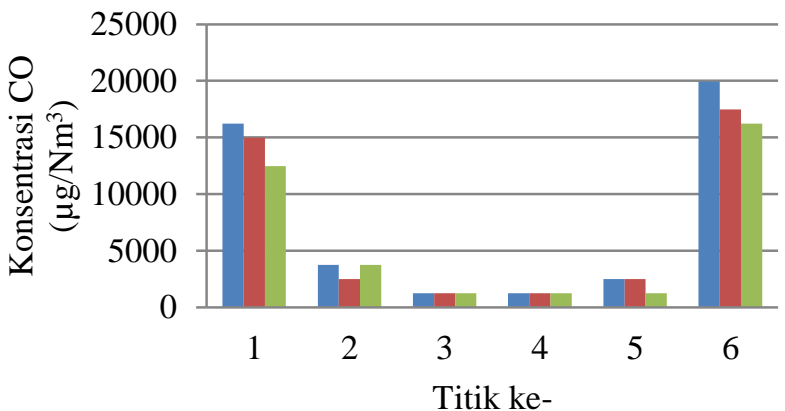

c. Kamis ke-3

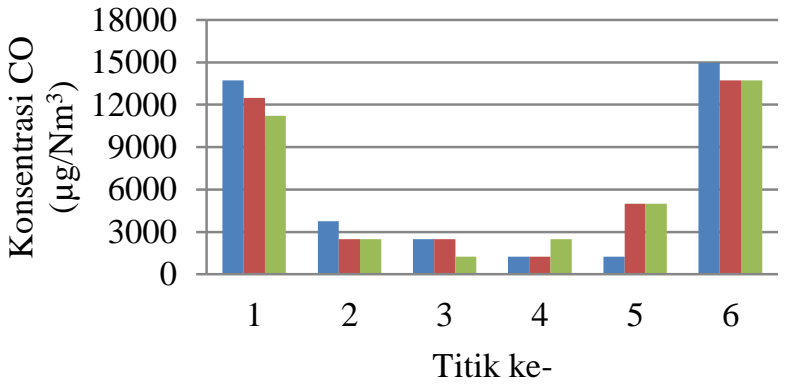

d. Kamis ke-4

Gambar 1 Grafik Nilai Konsentrasi CO Pada Hari Kamis (Hari Kerja)

Keterangan : $\square$ : Jarak 0m, $\square$ : Jarak 5m $\square$ :Jarak 10m

Gambar 1, nilai konsentrasi CO tertinggi berada pada titik 6 jarak Om dari sumber yang terletak pada persimpangan jalan Gajah Mada, Jalan Pahlawan dan Jalan Veteran dengan nilai konsentrasi CO sebesar $18.708 \mu \mathrm{g} / \mathrm{Nm}^{3}$ (kamis $\mathrm{ke}-1$ ), $12.472 \mu \mathrm{g} / \mathrm{Nm}^{3}$ (Kamis ke-2), $19.955 \mu \mathrm{g} / \mathrm{Nm}^{3}$ (Kamis ke-3), $14.967 \mathrm{\mu g} / \mathrm{Nm}^{3}$ (Kamis ke-4). Hal ini di pengaruhi oleh adanya vegetasi berupa pepohonan yang terdapat di titik pertama sedangkan pada titik 6 tidak terdapat pepohonan besar seperti di titik pertama. Adanya pepohonan inilah yang memungkinkan terjadinya perbedaan nilai konsentrasi CO.

Nilai konsentrasi CO tidak hanya di pengaruhi oleh letak lokasi dan jumlah kendaraan. Nilai konsentrasi CO juga dipengaruhi oleh :

a. Arah dan Kecepatan Angin

Arah angin selama pengukuran berasal dari timur laut menuju barat daya dengan kecepatan angin dominan yaitu berkisar antara $0,5 \mathrm{~m} / \mathrm{s}-2,1 \mathrm{~m} / \mathrm{s}$, dengan kecepatan angin tertinggi yaitu sebesar $2,1 \mathrm{~m} / \mathrm{s}$. Menurut Rahmawati (2008) menyatakan bahwa semakin cepat kecepatan angin pada suatu daerah, maka pencampuran polutan dari sumber emisi akan semakin besar yang mengakibatkan terjadinya pengenceran yang menyebabkan polutan di daerah tersebut akan semakin berkurang. 
b. Suhu

Suhu tertinggi terdapat pada Kamis di mingu ke-3 pada titik 6 yaitu pada persimpangan Jalan Gajah Mada, Jalan Veteran dan Jalan Pahlawan dengan hasil yaitu $27,7^{\circ} \mathrm{C}$ dan hasil Konsentrasi $\mathrm{CO}$ sebesar $16 \mathrm{ppm}$. Hasil ini lebih tinggi apabila dibandingkan dengan di titik pertama di minggu yang sama dengan suhu sebesar $26{ }^{\circ} \mathrm{C}$, di dapatkan hasil konsentrasi $\mathrm{CO}$ sebesar $13 \mathrm{ppm}$. Menurut Prabu (2009) suhu udara yang tinggi akan menyebabkan bahan pencemar dalam udara menjadi kering sehingga polutan akan cenderung lebih tinggi.

Berikut ini merupakan gambar analisis mengenai hasil konsentrasi CO di hari libur pada setiap titik pengambilan sampel CO.

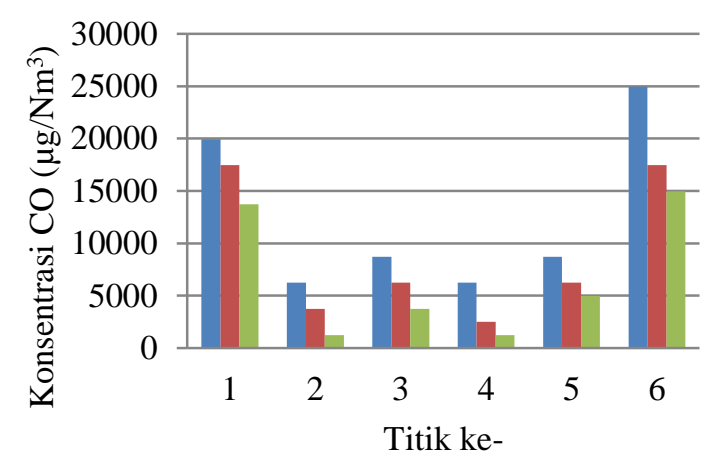

a. Minggu ke -1

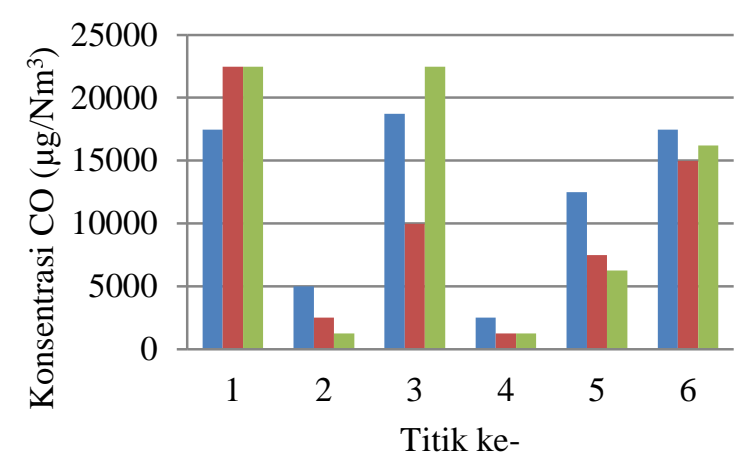

b. Minggu ke-2

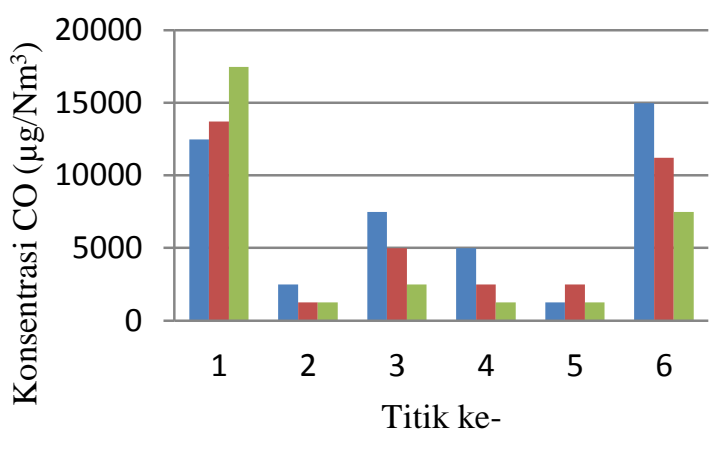

c. Minggu ke -3

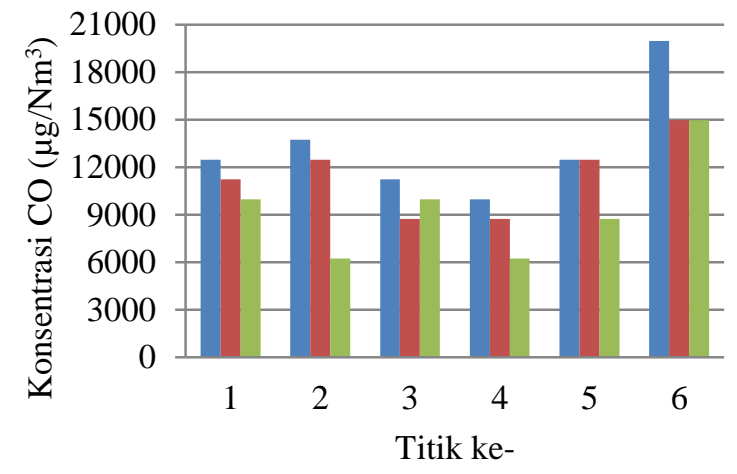

d. Minggu ke-4

Gambar 2. Grafik Konsentrasi CO Pada Hari Minggu (Hari Libur)

Keterangan : $\square$ :Jarak 0m, $\square$ :Jarak 5m $\square$ :Jarak 10m

Gambar 2 merupakan grafik nilai konsentrasi CO pada Minggu. Nilai konsentrasi CO tertinggi berada pada titik 6 jarak $0 \mathrm{~m}$ dari sumber titik 6 dengan jarak $0 \mathrm{~m}$ dari sumber yang terletak pada persimpangan jalan Gajah Mada, Jalan Pahlawan dan Jalan Veteran dengan nilai konsentrasi CO sebesar $22.944 \mu \mathrm{g} / \mathrm{Nm}^{3}$ di Minggu pertama, $22.450 \mu \mathrm{g} / \mathrm{Nm}^{3}$ di Minggu ke-2, $17.461 \mu \mathrm{g} / \mathrm{Nm}^{3} \mathrm{di}$ Minggu ke-3, dan $19.955 \mu \mathrm{g} / \mathrm{Nm}^{3}$ di Minggu ke-4. Pada titik 6 ini merupakan pertemuan arus lalulintas dan terdapat jalan penghubung (Jalan Tol) yang digunakan sebagai jalur keluar dan masuk kota, di ketahui pula pada persimpangan Jalan tersebut terdapat pasar tradisional pasca rekonstruksi yang pada malam hari digunakan sebagai tempat wisata malam berupa warung kopi maupun jajalan malam seperti lamongan dan lain sebagainya. Hal tersebut dapat menjadi penyebab tingginya nilai konsentrasi $\mathrm{CO}$ di titik tersebut. Faktor metereologi yang berpengaruh terhadap nilai konsentrasi CO antara lain :

a. Arah dan Kecepatan Angin

Arah angin selama pengukuran berasal dari timur laut menuju barat daya dengan kecepatan angin dominan selama waktu pengukuran berkisar antara $0,5 \mathrm{~m} / \mathrm{s}-2,1 \mathrm{~m} / \mathrm{s}$. 
b. Suhu

suhu tertinggi terdapat pada hari Minggu di minggu ke-2 dengan nilai sebesar $29,8{ }^{\circ} \mathrm{C}$. Nilai konsentrasi gas karbon monoksida (CO) pada malam hari (hari libur) cenderung lebih tinggi di bandingkan dengan konsentrasi CO di pagi hari (hari kerja). Hal ini di sebabkan suhu udara pada malam hari lebih lembab apabila dibandingkan di siang hari. Menurut Dirgantara (2014) pada saat siang hari dengan kondisi cuaca cerah, suhu udara akan tinggi akibat sinar matahari yang diterima sehingga akan mengakibatkan pemuaian udara. Pemuaian udara ini mengakibatkan pengenceran konsentrasi gas pencemar. Berdasarkan hal tersebut maka dapat dipahami bahwa nilai konsentrasi CO pada hari kerja akan terlihat lebih kecil apabila dibandingkan dengan nilai konsentrasi CO pada hari libur

B. Pengaruh Nilai Konsentrasi Gas Karbon Monoksida (CO) Terhadap Jarak Pengambilan Sampel

Untuk mengetahui adanya pengaruh jarak pengambilan sampel dengan kadar nilai konsentrasi gas CO maka digunakan analisis statistika Non Parametik Kruskal Wallist yang diolah dengan menggunakan program SPSS 21. Berikut ini merupakan hasil output dari hasil uji statistika Non Parametik Kruskal Wallist :

Tabel 3. Hasil Analisis Kruskal-Wallis Test Ranks

\begin{tabular}{|c|c|c|c|}
\hline Hari & Jarak & $\mathrm{N}$ & Mean Rank \\
\hline \multirow{3}{*}{ Minggu } & 0 & 24 & 42,58 \\
\hline & 5 & 24 & 35,56 \\
\hline & 10 & 24 & 31,35 \\
\hline \multicolumn{2}{|c|}{ Tot } & 72 & \\
\hline
\end{tabular}

\begin{tabular}{|l|r|}
\hline & \\
\hline Chi-Square & 3,55 \\
df & 2 \\
Asymp.Sig & 0,169 \\
\hline
\end{tabular}

dalam penelitian ini rumusan hipotesis yang digunakan yaitu :

HO : menyatakan tidak adanya hubungan dan pengaruh yang signifikan antara nilai konsentrasi CO dengan jarak pengambilan

$\mathrm{Ha}$ : menyatakan adanya hubungan dan pengaruh yang signifikan antara nilai konsentrasi $\mathrm{CO}$ dengan jarak pengambilan.

Dengan syarat penentuan hipotesis apabila $\mathrm{H} \leq \mathrm{X}^{2} \alpha ; \mathrm{K}-1$ maka hipotesis $\mathrm{HO}$ ditolak yang menyatakan bahwa hipotesis $\mathrm{Ha}$ akan diterima sedangkan apabila : $\mathrm{H}>\mathrm{X}^{2} \alpha$; K-1 maka hipotesis $\mathrm{HO}$ diterima yang menyatakan bahwa hipotesis $\mathrm{Ha}$ akan ditolak. Nilai taraf signifikansi $(\alpha)$ yang digunakan sebesar $5 \%$. Berdasarkan tabel melihat nilai yang didapat adalah $\mathrm{H} \leq \mathrm{X}^{2} \alpha ; \mathrm{K}-1(0,251 \leq$ $2,767)$ maka dapat di simpulkan bahwa hipotesis $\mathrm{HO}$ ditolak yang menyatakan bahwa hipotesis $\mathrm{Ha}$ diterima dengan pengertian nilai konsentrasi $\mathrm{CO}$ memiliki pengaruh yang signifikan terhadap variasi jarak pengambilan sampel.

\section{Pengaruh Nilai Konsentrasi Gas Karbon Monoksida (CO) Terhadap Baku Mutu Udara Ambien}

Nilai konsentrasi saat pengukuran berlangsung selama satu (1) menit pengukuran sedangkan pada baku mutu udara ambien untuk gas karbon monoksida di tetapkan selama 1 jam pengukuran dengan baku mutu sebesar $30.000 \mu \mathrm{g} / \mathrm{Nm}^{3}$ atau sebesar $26 \mathrm{ppm}$. Pada saat pengukuran didapatkan nilai konsentrasi tertinggi di hari kerja adalah sebesar $19.955 \mu \mathrm{g} / \mathrm{Nm}^{3}$ dan untuk hari libur didapatkan nilai konsentrasi CO sebesar $24.944 \mu \mathrm{g} / \mathrm{Nm}^{3}$. Dengan waktu pengukuran yang berlangsung selama 1 menit telah didapatkan hasil nilai konsentrasi CO yang cukup tinggi. Apabila dilakukan pengukuran selama 1 jam pengukuran, maka akan didapatkan nilai konsentrasi CO yang melebihi ambang baku mutu kualitas udara ambien

\section{Pengaruh Nilai Konsentrasi Gas Karbon Monoksida (CO) Terhadap Jarak Pengambilan Sampel}

Data konsentrasi CO yang di dapatkan menunjukkan hasil konsentrasi CO di bawah 100 ppm. Menurut Fardiaz (1992), ternyata kontak dengan CO pada konsentrasi yang relatif lebih rendah 
(kurang dari 100 ppm / kurang dari $115.519 \mu \mathrm{g} / \mathrm{Nm}^{3}$ ) juga dapat mengganggu kesehatan. Hal ini penting untuk diketahui terutama dalam hubungannya dengan masalah lingkungan karena konsentrasi CO di udara pada umumnya kurang dari $115.519 \mu \mathrm{g} / \mathrm{Nm}^{3}$. Pengaruh pada kesehatan manusia ini dipengaruhi oleh $\mathrm{CO}$ yang disebabkan oleh reaksi antara $\mathrm{CO}$ dengan Hemoglobin $(\mathrm{Hb}) \mathrm{di}$ dalam darah (Eko Bayu, 2012).

Secara normal sebenarnya darah mengandung $\mathrm{COHb}$ dalam jumlah sekitar $0,5 \%$. Jumlah ini berasal dari $\mathrm{CO}$ yang diproduksi oleh tubuh selama metabolisme heme, yaitu komponen pemecahan hemoglobin. Sisanya berasal dari CO yang terdapat di udara dalam konsentrasi rendah (Fardiaz, 1992). Tabel 4 berikut ini merupakan pengaruh konsentrasi $\mathrm{COHb}$ di dalam darah terhadap kesehatan manusia.

Tabel 4 Pengaruh Konsentrasi $\mathrm{COHb}$ di dalam Darah Terhadap Kesehatan Manusia

\begin{tabular}{|l|l|}
\hline $\begin{array}{c}\text { Konsentrasi } \mathrm{COHb} \\
\text { dalam darah (\%) }\end{array}$ & \multicolumn{1}{|c|}{ Pengaruh terhadap kesehatan } \\
\hline$<1,0$ & Tidak ada pengaruh \\
\hline $1,0-2,0$ & Penampilan agak tidak normal \\
\hline $2,0-5,0$ & $\begin{array}{l}\text { Pengaruhnya terhadap sistem syaraf sentral, reaksi panca indra tidak norm } \\
\text { terlihat agak kabur }\end{array}$ \\
\hline$\geq 5,0$ & Perubahan fungsi jantung dan pulmonari \\
\hline $10,0-80,0$ & $\begin{array}{l}\text { Kepala pusing, mual, berkunang-kunang, pingsan, kesukaran bernafas, } \\
\text { kematian }\end{array}$ \\
\hline
\end{tabular}

Sumber : Stoker dan Siregar,1972

Persen ekuilibrium $\mathrm{COHb}$ di dalam darah manusia yang mengalami kontak dengan $\mathrm{CO}$ pada konsentrasi kurang dari 100 ppm dapat di tentukan dengan menggunakan rumus sebagai berikut :

$\% \mathrm{COHb}$ dalam darah $=0,16 \times(($ konsentrasi $\mathrm{CO}$ di udara dalam ppm $)+0,5)$

Dengan contoh perhitungan sebagai berikut :

1. Diketahui nilai konsentrasi CO pada hari Kamis pada titik 6 di jarak $0 \mathrm{~m}$ terletak di persimpangan Jalan Gajah Mada, Jalan Jalan H.Agus Salim dan Jalan Diponegoro adalah sebesar 16 ppm. Maka perhitungannya adalah : \%COHb dalam darah $=0,16 \times(16+0,5)=2,64 \%$.

2. Diketahui nilai konsentrasi $C O$ pada hari Minggu pada titik titik 6 di jarak $0 \mathrm{~m}$ terletak di persimpangan Jalan Gajah Mada, Jalan Jalan H.Agus Salim dan Jalan Diponegoro adalah sebesar 20 ppm. Maka perhitungannya adalah : $\% \mathrm{COHb}$ dalam darah $=0,16 \times(20+0,5)=3,28 \%$

Berdasarkan hasil perhitungan mengenai persen ekuilibrium tersebut maka akan berpengaruh pada kesehatan manusia berupa terganggunya sistem syaraf sentral, reaksi panca indra tidak normal dan benda terlihat agak kabur. Menurut Yoky (2009) menyatakan bahwa konsentrasi gas CO sampai dengan 100 ppm masih dianggap aman kalau waktu kontaknya hanya sebentar.

\section{PENUTUP}

\section{A. Kesimpulan}

Adapun kesimpulan dari penelitian mengenai analisis konsentrasi gas karbon monoksida (CO) pada ruas Jalan Gajah Mada Pontianak yaitu :

1. Nilai konsentrasi gas karbon monoksida (CO) tertinggi di hari kerja (hari kamis) adalah sebesar $19.955 \mu \mathrm{g} / \mathrm{Nm}^{3}$ dengan kecepatan angin sebesar $0,1 \mathrm{~m} / \mathrm{s}$ dan suhu $27,7^{\circ} \mathrm{C}$ sedangkan untuk hari libur (hari minggu) di dapatkan konsentrasi CO yaitu sebesar $24.944 \mu \mathrm{g} / \mathrm{Nm}^{3}$ dengan kecepatan angin $0,2 \mathrm{~m} / \mathrm{s}$ dan suhu $28,7{ }^{\circ} \mathrm{C}$ yang berada pada titik yang sama yaitu titik 6 (persimpangan Jalan Gajah Mada, Jalan Veteran dan Jalan Pahlawan).

2. Berdasarkan hasil analisis dengan metode Kruskall Wallis menggunakan software SPSS 21 , nilai yang didapat adalah $\mathrm{H} \leq \mathrm{X}^{2} \alpha ; \mathrm{K}-1(0,251 \leq 2,767)$ maka dapat disimpulkan hipotesis $\mathrm{H} 0$ ditolak 
yang menyatakan bahwa hipotesis Ha diterima dengan pengertian nilai konsentrasi CO memiliki pengaruh yang signifikan terhadap variasi jarak pengambilan sampel. Semakin jauh jarak pengambilan dari sumber maka nilai konsentrasi $\mathrm{CO}$ akan semakin berkurang.

3. Faktor metereologi berpengaruh terhadap konsentrasi CO di Jalan Gajah Mada Pontianak. Meningkatnya suhu udara mengakibatkan nilai konsentrasi $\mathrm{CO}$ akan meningkat, sedangkan kecepatan angin yang semakin meningkat menyebabkan nilai konsentrasi $\mathrm{CO}$ akan berkurang.

\section{Ucapan Terima Kasih}

Penulis mengucapkan terima kasih yang sebesar-besarnya kepada Allah SWT atas rahmat dan karunia yang telah diberikan selama ini. Kedua orang tua yang telah memberikan semangat dan do'a. Penulis juga mengucapkan terimakasih kepada kepada Ibu Yulisa Fitrianingsih, ST., MT. Dan Ibu Dian Rahayu Jati,ST.,MT. sebagai pembimbing serta Ibu Rizki Purnaini, ST., MT. dan Ibu Isna Apriani, ST., M.Si sebagai penguji. Serta teman-teman dan semua pihak yang tidak dapat saya sebutkan satu persatu.

\section{DAFTAR PUSTAKA}

Eko, B. 2012. Pengaruh Kepadatan Kendaraan Bermotor Terhadap Konsentrasi Karbon Monoksida Ambien (Studi Kasus Jalan Taman Siswa Yogyakarta). Universitas Gajah Mada. Yogyakarta.

Dirgantara, Lapan. 2014. Pengaruh Emisi Polutan Udara dari Jalan Raya Terhadap Kualitas Udara Ambien. Diakses 15 Febuari 2014. www.dirgantara-lapan.or.id

Fardiaz, S. 1992. Polusi Air dan Udara. Yogyakarta: Kanisius.

Firda,M. 2012. Studi Penanganan Kemacetan Lalu Lintas Pada Jalan Gajah Mada Pontianak. Universitas Tanjungpura. Pontianak

Fitri Lukiastuti. 2012. Statistika Non Parametris. CAPS. Yogyakarta.

Kalimantan Barat.

Prabu,P. 2009. Aspek Klimatologis Pencemaran Udara. Diaskes 10 April 2013. putraprabu.wordpress.com/../aspek-k-klomatologis-pencemaran-udara

Praja. 2006. Gas Penyebab Emisi Udara. Yogyakarta: Kanisius.

Rahmawati,M. 2008. Pola Spasial Gas Karbon Monoksida (CO) di Kota Jakarta. Universitas Indonesia. Jakarta

Riduwan, 2011. Dasar-dasar Statistika. Alfabeta.Bandung

Stoker, H.S dan Siregar S.L. 1972. Environmental Chemistry : Air and Water Pollution. Scott, Foresman and Co., London.

Wardhana, W. A. 2004. Dampak Pencemaran Lingkungan. Yogyakarta: Andi.

Yoky Edy,S. 2009. Karbon Monoksida dan Dampaknya Terhadap Kesehatan. Dipetik 16 November 2013, dari Chem-is-try.org : http://www.chem-istry.org/artikel_kimia/kimia_lingkungan/karbonmonoksida-dan-dampaknya-terhadapkesehatan/

Zendrako, E. 2010. Pengukuran Kadar Gas Pencemar Nitrogrn Dioksida Di Udara Sekitar Kawasan Industri. Medan: Universitas Sumatera Selatan. 